\title{
Unveiling Wrongful Convictions Between the U.S. and Italy:
}

\author{
Cross-Learning From Each Other's Mistakes
}

\author{
Luca Lupária \\ Full Professor of Criminal Procedure at the University of Rome III. Director of the Italy \\ Innocence Project. President of the European Innocence Network. \\ Chiara Greco \\ Ph.D. Candidate in "Law and Social Change" at the University of Rome III. ${ }^{1}$
}

This paper focuses on the issue of wrongful convictions as it emerged in the U.S.A. during the nineties and subsequently gained attention throughout Europe. The first part focuses on the factors that have brought the issue of wrongful convictions to light and on the impact that the American experience has had on the European Criminal Systems' acknowledgment of the problem. The second part suggests that the perspective of the Italian jurist might be privileged when confronted with the topic of wrongful convictions, as the Italian criminal justice system was designed to combine the best aspects of both inquisitorial and adversarial systems. For this reason, one would expect the Italian system as generating few wrongful convictions. Facts and figures, however, do not support this expectation. The third part therefore focuses on those that might be the main causes for wrongful convictions within the Italian system, and it subsequently points out one major flaw of the Italian approach to the issue of wrongful convictions: the absence of a national database providing detailed information on previous cases of wrongful convictions. The paper then takes the U.S. National Registry of Exonerations and the establishment of conviction integrity units as positive examples from which Italy should learn. The conclusive part highlights one positive aspect of the Italian system: the limitations to plea bargaining and suggests that they might be taken as an example in other countries' reforms of such mechanism.

I. Introduction: The Evolution on the Perception of Wrongful Convictions; The Long Path from the U.S. to Europe

II. The Italian System and its "Privileged Perspective" on Wrongful Convictions

III. Learning from the Americans: The Need for a National Registry of Exonerations and $A d$ Hoc Commissions

A. The Most Common Causes of Wrongful Convictions Discovered in the U.S., Happening in Italy

a. False Confessions

b. Forensic Errors

c. Misidentification

d. Pentiti: the Italian Counterpart of U.S. Jailhouse Informants?

B. Learning from the Americans: The Need for a National Registry of Exonerations and Conviction Integrity Units

IV. Conclusions, Learning from the Italians: Plea Bargaining Limitations

\footnotetext{
${ }^{1}$ This paper is, in its entirety, the result of a shared reflection of the authors; however, Prof. Luca Lupária drafted paragraphs I and II while Chiara Greco drafted paragraphs III and IV.
} 


\section{Introduction: The Evolution on the Perception of Wrongful Convictions; The Long Path from the U.S. to Europe}

In one of his first television appearances of 2020, Italy's Ministry of Justice has stated, twice, that "innocent people don't end up in jail". ${ }^{2}$ The latest information concerning unlawful detentions, provided by the Minister of Economics, however, proves quite the opposite. Between 1991 and 2018, indeed, approximately 27,500 cases of unjust detention ${ }^{3}$ and 153 cases of wrongful conviction have been reported in Italy. ${ }^{4}$ While not all of those individuals might have been factually innocent, ${ }^{5}$ most of them were, indeed, legally innocent, meaning that it was ascertained there was not sufficient evidence to convict them. This is to mean that, in fact, innocent people do 'end up in jail', and any modern State is bound to ask itself what are the reasons behind such past mistakes and what are the instruments that might help avoiding them in the future.

As it is well re-known, the starting point of the ever-increasing debate concerning wrongful convictions can be traced back to the ' $90 \mathrm{~s}$, in the U.S., and has profoundly overcome the American boundaries ever since. Albeit there had been scholars that had previously brought attention to such an issue, ${ }^{6}$ the nineties are still considered to be the moment from which academics and law practitioners started to take it 'seriously', analyzing cases of previous convictions in order to have them overturned and to shed light on the causes of such mistakes. ${ }^{7}$ Scholars worldwide tend to agree that, before the nineties, little space was given to the issue because of a conservative

${ }^{2}$ Online: 〈http://www.today.it/politica/bonafede-innocenti.html >. The article contains both the Ministry's statement and his following explanations.

${ }^{3}$ With this expression we refer to those instances where an individual was held in pre-trial detention, according to Article 285 of the Italian code of criminal procedure (from now on, also "cpp"), and afterwards was acquitted of all charges (or his/her detention proved to be unjustified).

${ }^{4}$ Online: 〈https://www.errorigiudiziari.com/errori-giudiziari-quanti-sono/>. Bear in mind that the data herein provided are not coming from the Minister of Justice but from the Minister of Economics and Finance; indeed, such data refers to the number of cases in which the State had to pay compensation to the individual. For this reason, the numbers herein provided might be different from the 'real' number of 'ascertained' wrongful convictions, as not every 'exoneree' may seek or be accorded financial compensation.

${ }^{5}$ We use the term 'factually innocent' to indicate those individuals that did not materially commit the crime they were accused of. The difference between material innocence and probative innocence (meaning there is no sufficient evidence to prove guilt) is well explained by Larry Laudan, Truth, Error and Criminal Law. An Essay in Legal Epistemology (New York: Cambridge University Press, 2006).

${ }^{6}$ Among others, see Edwin M Borchard, Convicting The Innocent: Sixty-Five Actual Errors Of Criminal Justice (Garden City: Garden City Publishing Company, 1932); Ruth Brandon \& Christie Davies, Wrongful Imprisonment: Mistaken Convictions And Their Consequences (Hamden: Archon Books, 1973); Jerome Frank \& Barbara Frank, Not Guilty (Garden City: Doubleday, 1957); Erie Gardner, Court Of Last Resort (New York: Pocket Books, 1952); Edward Radin, The Innocents (New York: William Morrow, 1964)

${ }^{7}$ In this respect, it is worth mentioning Hugo Bedau \& Michael Radelet, "Miscarriages of Justice in Potentially Capital Cases" (1987) 40:1 Stan L Rev 21; Scott Christianson, Innocent: Inside Wrongful Conviction Cases (New York: New York University Press, 2004); Ronald Huff, Arye Rattner \& Edward Sagarin, Convicted But Innocent: Wrongful Conviction And Public Policy (London: Sage, 1996); Barry Scheck, Peter Neufeld \& Jim Dwyer, Actual Innocence: Five Days To Execution And Other Dispatches From The Wrongly Convicted (New York: Doubleday, 2000) [Scheck, Neufeld \& Dwyer]. 
approach concerning justice. ${ }^{8}$ The almost universally accepted reason behind such a rapid drift in public and institutional attention towards wrongful conviction is twofold.

On the one hand, during the nineties science had reached the ability to match with sufficient precision DNA profiles, and those techniques started to be used in court; ${ }^{9}$ as it has been noted, "before the invention of DNA testing, the problem of convicting the innocent remained largely out of sight. Many doubted that a wrongful conviction could ever occur". ${ }^{10}$ While DNA testing is frequently used to convict a suspect,,${ }^{11}$ it was deeply precious in securing hundreds of exonerations in cases where biological samples had not been tested or new technologies had emerged. ${ }^{12}$

On the other hand, and almost needless to recall, in 1992 professors Barry C. Scheck and Peter J. Neufeld founded the first 'Innocence Project' within the Benjamin N. Cardozo School of Law at Yeshiva University in New York City. As the project started to gain public acknowledgement for being able to effectively assist convicts and have them overturn their sentence, that what had begun as the legal clinic of a single U.S. University turned out to be a world-wide phenomenon. ${ }^{13}$ Innocence Projects started to flourish all around the U.S. and reached Europe, with Italy having its Innocence Project ${ }^{14}$ founded in late 2013 (the project is now based at Roma Tre University, and in 2014 was admitted to the Innocence Network). Those projects not only have been of incredible help to those that seek legal assistance, but - and perhaps more importantly - were able to draw the public's attention on the causes that lie behind wrongful convictions and helped foster academic research.

DNA testing and Innocence Projects, combined with the fact that, as many know, the U.S. has the largest prison population in the world and one of the highest percentages of individuals

\footnotetext{
${ }^{8}$ Ronald Huff \& Martin Killias, eds, Wrongful Convictions: International Perspectives on Miscarriage of Justice (Philadelphia: Temple University Press, 2008) 72 [Huff \& Killias]; Richard A Leo, "The Criminology of Wrongful Conviction: A Decade Later" (2017) 33 J Contemp Crim Just 82.

${ }^{9}$ In fact, the first time DNA was actually applied for identification purposes was in 1985, by Alec Jeffreys from the University of Leicester. See Huff \& Killias, ibid at 42.

${ }^{10}$ Brandon L Garrett, Convicting the Innocent: When Public Prosecutors Go Wrong (Cambridge: Harvard University Press, 2011) 5 [Garrett]. The work has been recently updated in Brandon L Garrett, Convicting the Innocent Redux in Daniel Medwed, ed, Wrongful Convictions and the DNA Revolution: Twenty-Five Years of Freeing the Innocent (Cambridge: Cambridge University Press, 2017) 40.

${ }^{11}$ Indeed, as noted by Luca Lupária, "Cultura della Prova ed Errore Giudiziario: Il Processo Penale in Discussione" in Giovanni Paolozzi, Luca Marafioti \& Luca Lupária, eds, Errori Giudiziari e Background Processuale (Torino: Giappichelli, XV, 2015) [Paolozzi, Marafioti \& Lupária] XI, DNA testing in Europe is still conceived at its core as a decisive proof of guilt.

${ }^{12}$ According to the National Registry of Exonerations on 2 February 2020 out of 2565 exonerees, 504 have had DNA play a decisive role in their exoneration; see online:

$\langle$ https://www.law.umich.edu/special/exoneration/Pages/Exoneration-by-Year.aspx $>$. Another good source of information and data on 367 DNA exonerations is Convicting the Innocent, an online Database, online: <www.convictingtheinnocent.com> that updates the research by Professor Brandon Garrett, supra at note 10.

${ }^{13}$ Jon B Gould \& Richard A Leo, "One Hundred Years Later: Wrongful Convictions After A Century Of Research" (2010) 100:3 J Crim L \& Criminol 825 [Gould \& Leo]; Allison D Redlich \& John Petrila, eds, "The Age of Innocence: Miscarriage of Justice in The 21st Century" (2009) 27 Behav Sci \& L 297; Scheck, Neufeld \& Dwyer, supra note 7. ${ }^{14}$ Online: <https://italyinnocenceproject.org〉. The Italy Innocence Project is directed by Professor Luca Lupária.
} 
detained, ${ }^{15}$ made it possible for the U.S. to become the home of the largest set of wrongful convictions brought to light by lawyers (and not only using DNA technology). Thanks to the immense public impact that such a high number of reversed convictions had, scholars throughout the globe have devoted their attention to studying the causes of wrongful convictions and to the elaboration of possible remedies.

Among the most positive outcomes of the nineties' revolution concerning wrongful convictions stands the fact that it has transcended American boundaries; indeed, the exonerees' phenomenon has brought scholars throughout Europe to analyze their own past judicial decisions and legal systems, in order to verify whether the same virus existed also within the Continent. Unsurprisingly, the answer was positive, and Europe was obliged to face a long-standing taboo, the reluctance to recognize that European criminal justice systems can, indeed, generate wrongful convictions. ${ }^{16}$

Thanks to that, lawmakers throughout Europe are slowly improving remedies to overturn convictions, while some States have created ad hoc mechanisms appointed to verify the necessity to reopen final decisions. ${ }^{17}$ In addition to this, the exonerees' outburst has offered the opportunity for continental jurists to reflect on the reliability of some traditional evidence, often overrated within courtrooms. ${ }^{18}$ Still, the shift towards 'safer' criminal justice systems is far from being

${ }^{15}$ Garrett, supra note 10 at 245. According to the statistics published by the Bureau of Justice Statistics of the U.S. Office of Justice Programs, online: <https://www.bjs.gov/index.cfm?ty=dcdetail\&iid=269> latest data available in 2017) that every year used to collect the data on the penitentiary situation in the U.S., in 2013, a peak of 1,574,700 inmates had been reached, E Ann Carson, "Prisoners in 2013" (U.S. Department of Justice, BJS, 2014) 1, diminished to 1,526,800 at 31 December 2015, E Ann Carson \& Elizabeth Anderson, "Prisoners in 2015" (U.S. Department of Justice, BJS, 2016) 1. Other important information on mass incarceration in the U.S. can be found on the "The Sentencing Project" website (http://www.sentencingproject.org/issues/incarceration/).

${ }^{16}$ See Huff \& Killias, supra note 8 with regard to: Chrisje Brant, "The Vulnerability of Dutch Criminal Procedure to Wrongful Conviction" at 157; Nathalie Dongois, "Wrongful Convictions in France: The Limits of "Pourvoien Révision" at 249; Isabel Kessler, "A Comparative Analysis of Prosecution in Germany and the United Kingdom: Searching for Truth or Getting a Conviction" at 213; Martin Killias, "Wrongful Convictions in Switzerland: The Experience of a Continental Law Country" at 139; Emil W Plywaczewski, Adam Górski \& Andrzej Sakowic, "Wrongful Convictions in Poland: From the Communist Era to the Rechtstaat Experience" at 273; Clive Walker \& Carole McCartney, "Criminal Justice and Miscarriages of Justice in England and Wales" at 183. See also Luca Lupária, ed, Understanding Wrongful Conviction: The Protection of The Innocent Across Europe And America (Milano: Wolters Kluwer, 2015) 2 [Lupária 1].

${ }^{17}$ See Ulf Stridbeck \& Syein Magnussen, "Prevention of Wrongful Convictions: Norwegian Legal Safeguards And The Criminal Cases Review Commission" (2012) 80:4 U Cin L Rev 1373; Syein Magnussen, "Opening potentially Wrongful Convictions - Look to Norway" (2012) 58:2 Crim LQ 267. For an overview of the Dutch experience see Theodore A De Roos and Johannes F Nijboer, "Wrongfully Convicted: How the Dutch Deal with the Revision of their Miscarriages of Justice" (2001) 22 Crim LF 567. See Geert-Jan Alexander Knoops, Redressing Miscarriages of Justice: Practice and Procedure in National and International Criminal Law Cases (The Hague: Sdu Uitgevers, 2006) [Knoops].

${ }^{18}$ Lupária 1, supra note 16 at 3. On eyewitness identification see Amy Bradfield Douglass \& Nancy K Steblay, "Memory Distortion in Eyewitnesses: A Meta-Analysis of the Post-Identification Feedback Effect" (2006) 20 Applied Cognitive Psychol 859. On the accuracy level of DNA as incriminating evidence see Daniel S Medwed, ed, "Symposium: Beyond Biology, Wrongful Conviction in The Post-DNA World" (2008) Utah L Rev 1. On the risks of 
completed, as cases of wrongful convictions are still quite frequent and national authorities are not always willing to admit their flaws - as we noted at the beginning of this article.

In this paper, therefore, we seek to provide readers with the perspective of an Italian jurist on wrongful convictions: as many of its continental counterparts, Italy as well has to face its own 'wrongful convictions' problem. Despite the term 'judicial error' being contained in Italy's Constitution, ${ }^{19}$ revision instances are rarely welcomed by appeal courts, while thousands of individuals every year seek compensation for the unjust detention they have suffered.

\section{The Italian System and its "Privileged Perspective" on Wrongful Convictions}

Some authors have argued in the past that in order to understand how to prevent wrongful convictions, an 'interesting thought exercise' would have been to imagine a new, hybrid criminal justice system, combing the best aspects of both inquisitorial and adversarial systems. ${ }^{20}$

Ideally speaking, then, this would entail that when confronted with the topic of wrongful convictions, the perspective of those who are surrounded by the Italian criminal procedure should be privileged. Indeed, since 1988's reform, the Italian criminal justice system stands out, among its European counterparts, for being the 'genuinely hybrid' one, showing both inquisitorial and adversarial traits. ${ }^{21}$

new scientific methods see Brandon L Garrett \& Peter Neufeld, "Invalid Forensic Science Testimony and Wrongful Convictions" (2009) 95 VA L Rev 1.

${ }^{19}$ Article 24 para 4 of the Italian Constitution states that "The law shall define the conditions and forms of reparation in case of judicial errors".

${ }^{20}$ Martin Killias \& C Ronald Huff, Wrongful Convictions and Miscarriages of Justice - What Did We Learn? in Martin Killias \& C Ronald Huff, eds, Wrongful Convictions and Miscarriages of Justice: Causes and Remedies in North American and European Criminal Justice System (New York: Routledge, 2013) 393 [Killias \& Huff].

${ }^{21}$ For an in depth yet approachable summary of Italian criminal procedure see Luca Lupária \& Mitja Gialuz, "The Italian Criminal Procedure Thirty Years after the Great Reform" (2019) 1 Roma Tre L Rev 26 [Lupária \& Gialuz]; Luca Marafioti, "Italian Criminal Procedure: A System Caught Between Two Traditions" in John Jackson, Maximo Langer \& Peter Tillers, eds, Crime, Procedure and Evidence in a Comparative and International Context (Portland, Hart, 2008) 81 [Jackson, Langer \& Tillers]; for an English translation of the Italian code of criminal procedure, it might be useful to refer to Mitja Gialuz, Luca Lupária \& Federica Scarpa, The Italian Code of Criminal Procedure: Critical Essays and English Translation (Milano: Wolters Kluwer, 2017) [Gialuz, Lupária \&Scarpa]. As it has been noted, any simplistic classification of the Italian system among the adversarial or inquisitorial ones ought to be avoided, Lupária \& Gialuz, ibid at 29. The system, notwithstanding having embraced a vast array of features traditionally pertaining to adversarial systems, still bears the traces of an inquisitorial past. See also Ennio Amodio, "The Accusatorial System Lost and Regained: Reforming Criminal Procedure in Italy" (2004) 52 Am J Comp L 489; Elisabetta Grande, "Italian Criminal Justice: Borrowing and Resistance" (2000) 48 Am J Comp L 227; Michele Panzavolta (2005) "Reforms and Counter-Reforms in the Italian Struggle for an Accusatorial Criminal Law System" (2005) 30 NCJ Int'l L \& Com Reg 577; William Pizzi \& Mariangela Montagna, "The Battle to Establish an Adversarial Trial System in Italy" (2004) 25 Mich J Int'l L 429. 
In fact, the Italian phase of pre-trial investigation is essentially governed by the public prosecutor (pubblico ministero) ${ }^{22}$ Albeit being part of the judiciary, she is entrusted with functions that differ significantly from those of the judge. The public prosecutor is indeed conceived as a party, like the defendant, though being bound by the compulsory prosecution principle ${ }^{23}$ and formally obliged to also investigate exculpatory evidence. ${ }^{24}$

At the end of the pre-trial phase the public prosecutor will either request the case to be brought to trial (richiesta di rinvio a giudizio) or to be dismissed (richiesta di archiviazione). These requests will be evaluated by another ad hoc judge, who will have to assess whether the evidence collected by the prosecutor is, prima facie, enough to sustain the accused at trial.

When the judge decides that the evidence is, indeed, sufficient, she will form two separate 'dossiers'; one will remain in the public prosecutor's office; the other one will be given to the trial judge and will contain only the minutes of those activities that, despite being carried out before the trial, are non-repeatable. This rule is aimed at avoiding that, in principle, the materials that were acquired during the investigation are shown to the trial judge, so that she can start the trial with a 'virgin mind' (tabula rasa) and that all evidence is gathered during the trial strictu sensu. ${ }^{25}$

The 1988 reform, indeed, has transposed into the Italian system the adversarial principles of orality, immediacy and confrontation: the accused has the right to be judged upon the evidence, and solely the evidence, which is formed during the trial in front of the trial judge, and she has the right to confront her accusers and cross-examine witnesses. ${ }^{26}$ Lastly, technical defence is compulsory throughout the trial and the suspect-accused benefits of 'the most radical protection' of her right to silence.

While most of the features we have described so far will be familiar to those that are used to adversarial systems, the Italian Code of Criminal Procedure still provides with multiple elements that reveal Italy's inquisitorial background. First, judges have the power to order evidence to be acquired ex officio, if they deem it necessary (see art. 422 and 507 c.p.p.). ${ }^{27}$ Moreover, judges can

\footnotetext{
${ }^{22}$ Her role is similar to that played by the District Attorney in the U.S.A., albeit they structurally differ - the public prosecutor being a magistrate as well as the judge.

${ }^{23}$ The principle is embedded in art 112 of the Italian Constitution; despite its formal proclaim, scholars tend to agree on the fact that, in reality, prosecutors enjoy wide discretion as to whether to prosecute or not an individual.

${ }^{24}$ According to Article 358 of the Italian Code of Criminal Procedure "The Public Prosecutor shall carry out any activity necessary for the purposes referred to in Article 326 and shall also investigate facts and circumstances in favor of the suspected person". See Luca Marafioti, 'Italian Criminal Procedure: A System Caught Between Two Traditions" in Jackson, Langer \& Tillers, supra note 21.

${ }^{25}$ Lupária and Gialuz, supra note 21 at 53; Julia Grace Mirabella, "Scales of Justice: Assessing Italian Criminal Procedure Through the Amanda Knox Trial” (2012) 30:1 BU Int'l LJ 235 [Mirabella].

${ }^{26}$ This 'golden rule', however, suffers multiple exceptions, and albeit the written material courts might use are formally limited, there is still an ongoing tendency to consider as evidence the results of the public prosecutor's investigation.

${ }^{27}$ Though these powers were designed to be used only in exceptional circumstances, Italian judges have widely resorted to them - struggling to adjust to the new passive role that the reform wanted them to play. See Luca Marafioti, "Italian Criminal Procedure: A System Caught Between Two Traditions" in Jackson, Langer, Tillers, supra note 21 at 93; the Author underlines that judges are still assuming a dominant position within the trial; even if such an attitude
} 
also question witnesses (albeit only after the parties' cross-examination) and indicate to the parties new issues that need to be addressed. Second, the Italian appellate system has been left mainly untouched by the reform, and still provides the parties with two additional 'instances' of judgment. ${ }^{28}$ Third, Italy did not fully implement the U.S plea bargaining mechanism: indeed, its Italian version (so called 'patteggiamento') is only available for minor offences and has to be subjected to a deep and comprehensive evaluation by the judge. ${ }^{29}$

If the original plan of 'taking the best from the adversarial tradition while clinging to the positive aspects of the inquisitorial one' had been perfectly completed, then, one would expect the Italian system as generating few, if any, wrongful convictions.

Facts and figures, however, do not support this expectation. Albeit having undergone a deep and complex renovation process, the Italian system is far from perfect - especially when it comes to wrongful convictions. As it has been noted at the beginning of this paper, within the (not so long) span of less than thirty years, Italy had to face at least 153 cases of wrongful conviction. ${ }^{30}$ We use the expression 'at least', as this number is in no way truly representative of the real proportion of wrongful convictions. Indeed, a reversal of a previous final judgment (this being, strictu sensu, a wrongful conviction) can only occur in extremely exceptional circumstances and - in addition to this - the Ministry of Justice provides no official data as to how many and which criminal cases turned out to be wrongful convictions.

Moreover, procedural reforms had little impact on another worrisome feature of the Italian criminal system: the 'use and abuse' of pre-trial detention. Needless to remembers, the average Italian criminal trial is extremely lengthy when compared to other European States or the U.S. ${ }^{31}$ The slowness of the Italian criminal justice machine has two perverse effects: on the one hand, it can cause the suspect to be acquitted because of statutory limitations, thus undermining the deterrent effect of criminal law. On the other hand, it leaves citizens unsatisfied, as they perceive that the State is not doing enough to effectively keep society safe and prosecute those responsible for serious crimes.

To counter these effects, pre-trial detention is often abused, ${ }^{32}$ in the sense that it is resorted to more often than necessary, so as to re-assert the deterrent effect of criminal justice and satisfy the public's demand for safety. This entails that, pending trial, a large part of Italian suspects suffers long periods of pre-trial detention, sometimes multiple years, before being found eventually not guilty. Although pre-trial detention cannot be imposed for minor offences, and is virtually

\footnotetext{
could be attributed to the need to search for the truth, in practice it serves as a counter-balance for weaknesses in prosecutions. See Mirabella, supra note 25.

${ }^{28}$ As it has been noted, such an appellate system reveals that the Italian legislator had no real trust in the ability of the first-instance trial to reach the truth, despite its 'adversarial' renovation. It has additionally been noted that "the appeals process plays as large a part in the effort to ascertain truth as the trial itself" Mirabella, supra note 25 at 253.

${ }^{29}$ See art $444 \mathrm{ff}$ cpp.

${ }^{30}$ Online: <https://www.errorigiudiziari.com/errori-giudiziari-quanti-sono/>.

${ }^{31}$ See online: 〈https://rm.coe.int/rapport-avec-couv-18-09-2018-en/16808def9c > at 311.

${ }^{32}$ Such a phenomenon has been described by 'always more alarming', see Frederica Centorame, "Valutazione del Fumus Commissi Delicti e Ingiusta Detenzione Cautelare" [Centorame] in Paolozzi, Marafioti \& Lupária, supra note 11 at 5.
} 
limited in time, those suspected of having committed serious crimes can spend in pre-trial detention up to six years. Moreover, when it comes to mafia type organizations or terrorism, pretrial detention seems to be the rule rather than the exception. ${ }^{33}$

The misuse of pre-trial detention explains why during the course of less than thirty years there have been approximately 27,500 cases of wrongful detention, (i.e., cases in which there was no justification to detain the suspect or she was later acquitted of all charges). ${ }^{34}$

The numbers differ significantly if one considers the cases of those who obtained a 'revision' of their conviction pursuant to art. 630 c.p.p. (the Italian equivalent of U.S. exonerees): up to 2018, approximately 153 cases had been reported. This shows that Italy's main concern is indeed that of wrongful pre-trial detention, rather than wrongful convictions (though the latter occur as well). However, since some evidence (serious indicia of guilt) is needed for prosecutors to obtain pre-trial detention, flawed evidence can be both the cause of wrongful convictions and unjust detentions.

The overview provided in the last paragraphs is not intended to lead the reader to believe that the huge 1988 reform was useless or, worse, detrimental. On the contrary, the original structure of the 1930 criminal procedure code, born under the fascist era, could no longer be deemed compatible with the Italian Constitution or the European Convention on Human Rights. Change was needed and the transplant of many adversarial principles has profoundly strengthened the rights of the accused.

Such a transplant, however, simply did not solve the issue of wrongful conviction, thus making it necessary to ask ourselves 'What is going wrong and how to fix it?' ${ }^{35}$ In answering these questions we believe that there is still much room for the Italian system to learn from its American counterpart, or maybe better, to learn from the multiple and efficient ways in which U.S. State agencies and academics have responded to the rise of the 'innocent movement'. On the other hand, we would also like to point out some 'Italian pros' that, if implemented in the U.S. might reduce the 'American risk' of wrongful convictions.

\footnotetext{
${ }^{33}$ Some authors speak of "a nearly compulsory detention system for more severe offences" see Lupária \& Gialuz, supra note 21 at 40 . See also Centorame, ibid at 7, where the author underlines how - with respect to a list of crimes set out in art 273 (3) cpp - pre-trial detention is applied automatically, simply because of the nomen iuris of the crime that the suspect has allegedly committed.

${ }^{34}$ Online, supra note 30.

${ }^{35}$ Let's bear in mind, however, that 'official numbers' of compensation accorded to unlawfully detained/convicted individuals only started to be provided in 1991, thus after the new code was adopted. This is to say that we have no way of 'officially' comparing the previous and the actual criminal justice system when it comes to wrongful convictions.
} 


\section{Learning from the Americans: The Need for a National Registry of Exonerations and Ad Hoc Commissions}

In this part, after having identified the four factors that have been deemed by scholars the most prominent 'evidentiary' causes of wrongful convictions ${ }^{36}$ - we will try to understand whether such causes can be said to operate in the Italian system as well. Spoiler alert, the lack of data will render our mission quite complex, thus leading us to propose some possible reforms that we consider indispensable in order to better understand the legal and root causes of the Italian wrongful convictions.

\section{A. The Most Common Causes of Wrongful Convictions Discovered in the U.S. Happening in Italy}

\section{a. False Confessions}

One of the causes of wrongful convictions among which there seems to be almost unanimous consensus is that of false or coerced confessions: ${ }^{37}$ though it may seem highly unreasonable, and therefore rare, for someone to confess to a crime she didn't commit, ${ }^{38}$ decades of in-depth studies have proved quite the opposite. ${ }^{39}$

${ }^{36}$ Knoops, supra note 17; Mark Godsey, Blind Injustice (Oakland: University of California Press, 2007) 201 [Godsey 1]. We have chosen to focus on false confessions, forensic errors, misidentification and jailhouse informants for two reasons; first, there is unanimous consensus of them being the main 'unreliable evidence' concern; second, as with respect to this specific causes there is some Italian literature and case-law we can draw upon.

${ }^{37}$ Specialized literature on the issue of false confessions is extremely vast: see Steven A Drizin \& Richard A Leo, "The Problem Of False Confessions In The Post-DNA World" (2004) 82 NCL Rev 891; Steven A Drizin \& Marissa Reich, "Heeding the Lessons of History: The Need for Mandatory Recording of Police Interrogations to Accurately Assess the Reliability and Voluntariness of Confessions" (2004) 52 Drake L Rev 619; Luca Lupária, La Confessione dell'Imputato nel Sistema Processuale Penale (Milano: Giuffrè, 2006) [Lupária 2]; Mark Godsey, "Shining the Bright Light on Police Interrogation in America" (2009) 6 Ohio St J Crim L 711 [Godsey 2]; Gisli Gudjonsson, The Psychology of Interrogations and Confessions: A Handbook (Chichester: John Wiley, 2003); Saul Kassin, "The Psychology of Confession Evidence" (1997) 52 Am Psychol 221; Saul Kassin \& Katherine Neumann, "On the Power of Confession Evidence: An Experimental Test of the Fundamental Difference Hypothesis" 21 Law \& Human Behav 460; Richard A Leo, "False Confessions: Causes, Consequences and Implications" (2009) 37:3 J Am Academy Psy $\&$ L 344. See also Garrett, supra note 10 whose second chapter is entirely devoted to the issue of coerced confessions. More recently, see Godsey 2, supra note 37 at 136.

${ }^{38}$ Scholars have pointed out that for a long time it has been vigorously denied that false confessions were even an existing phenomenon; the perspective changed as soon as DNA testing unveiled the falsity of previous confessions. See Garrett, supra note 10 at 16.

${ }^{39}$ A suspect or even someone who is not in the radar of the police might confess to an unsolved crime for multiple reasons: she might be seeking public attention, she might hope to protect a loved one who she believes is the culprit, she might hope to receive a more lenient sentence; more frequently, the confession is simply coerced by police pressure. Other factors that have been unveiled as underpinning false confessions are the need to build an alibi for a different crime, mental weakness, wrong self-beliefs. The more the subject is vulnerable, the interrogation techniques harsh and the evidence apparently irrefutable, the more a false confession will seem an easy solution. Studies have also shown that - besides blatant cases in which the confession is violently obtained - the most common way for police officers to obtained a detailed confession of a crime the suspect did not commit is leaking to her facts of the crime she 
In most American cases in which false confessions were obtained, the interrogation was not recorded at all or, at best, only some final parts of it were recorded. Despite the suspects having also provided information that was inconsistent with the real facts of the case, false confessions were still considered reliable and ended up in a conviction. This is also due to the fact that, after having secured a confession, police frequently stopped the investigation and failed to investigate the inconsistencies of the case. ${ }^{40}$

Albeit false, and sometimes even blatantly so, confessions are still incredibly powerful evidence at trial, to the point where scholars doubt that juries have the ability to 'put a confession out of mind' even if told to do so. ${ }^{41}$

As opposed to the American experience, the issue of false confessions in Italy has not been made the object of a case based study; for this reason, it appears difficult both to assess the extent to which this phenomenon actually exists in our country and to verify its causes. If one only takes into account 'the law on the books', the Italian system does not seem to give much consideration to confessions within the criminal trial; ${ }^{42}$ indeed, confessions are not regulated by the Italian Code of Criminal Procedure, they are not formally considered as evidence and there is no legal guideline as to how judges should evaluate them. The Code takes confessions into account only to allow the trial to commence without a preliminary hearing if the suspect has confessed during the interrogation (giudizio direttissimo).

Furthermore, Italian trials are conducted in front of professional judges, not laymen juries, thus theoretically decreasing the risk of the emotional impact brought by a confession. Only for specific (serious yet not technically complex) crimes there is a mixed panel composed by two professional judges and six jurors (Corte d'Assise, in line with the French legal tradition).

In addition to this, the Italian system seems to offer all it takes in order to avoid unnecessary pressure to be put on the suspect during interrogation. In fact, what the suspect has said during the interrogation conducted by the police can be used in court only if the accused's lawyer was present; furthermore, after a preventive measure has been executed, only the judge is authorized to interrogate the suspect, thus excluding both the police and the public prosecutor. Lastly, if the suspect is detained, her interrogation needs to be recorded so as to be admissible in court.

Notwithstanding the apparent lack of weight that the system puts on confessions, and all the guarantees mentioned above, there have been in fact cases where false confessions have

\footnotetext{
might not have otherwise known. The role of police malpractice in fabricating false confession is not a concern exclusive to the U.S.; for the UK experience it is worth mentioning Kessler in Huff \& Killias, supra note 8 at 234.

${ }^{40}$ See Garrett, supra note 10 at 32.

${ }^{41}$ Marvin M Zalman, "The Adversary System and Wrongful Conviction" in Huff \& Killias, supra note 8 at 71. Page 74 highlights that false confessions overwhelm the jury's decision-making abilities.

${ }^{42}$ Loredana Garlati "Miti Inquisitori: la Confessione tra Ricerca della Verità e Garanzie Processuali” in Luca Lupária \& Luca Marafioti, eds, Confessione, Liturgie della Verità e Macchine Sanzionatorie (Torino: Giappichelli, 2015) 70 [Lupária \& Marafioti].
} 
occurred. ${ }^{43}$ Setting aside a blatant case in which torture is believed to have been the cause of the confession, ${ }^{44}$ the other three cases that we have been able to identify do share the same traits of most of the cases that have been analyzed in the U.S. In one case, the suspect was mentally ill; ${ }^{45}$ in the second one, she was supposedly pressured by police, who told her she would have benefit from the confession and that there was other evidence against her and her accomplices; ${ }^{46}$ in the third case, he wanted to cast suspicion away from his daughter. ${ }^{47}$ While knowing that a few cases cannot serve as a solid basis to conduct an in-depth analysis, they seem to prove that no country is immune from the phenomenon of false confessions, and that the main causes are quite recurring.

In addition to this, Italian scholars have highlighted that the difference between 'the law on the books' and 'the law in action', when it comes to confessions, is quite striking. Confessions end up playing a decisive role in day-to-day judicial experience and shed their light on the whole pretrial investigation phase. Prosecutors do indeed set out 'traps' to stimulate the suspect's cooperation, pre-trial detention is used in order to gain confessions ${ }^{48}$ and there is an ongoing tendency to consider self-incriminatory statements even when obtained outside the criminal trial. ${ }^{49}$ Moreover, judges do attribute great value to confessions, and there is a tendency to allow convictions to be based solely on a confession, with no other evidence upholding the prosecutor's theory.$^{50}$ Lastly, judges do not frequently make use of the various confessions' reliability parameters that have been elaborated by psychology.

\section{b. Forensic Errors}

As we have noted in the introduction, forensic science, ${ }^{51}$ especially DNA profiling techniques is one of the main reasons that has brought the topic of wrongful convictions to light

\footnotetext{
${ }^{43}$ It has been indeed noted that the occurrence of false confessions is quite frequent; see Giulio Garofalo, "La Caduta Del Mito Della "Prova Regina": Confessione E Testimonianza" in Paolozzi, Marafioti \& Lupária, supra note 11 at 47.

${ }^{44}$ We are making reference to Giuseppe Gulotta, acquitted after 22 years spent in jail because of a confession that was obtained by torture; the case has been made the object of enormous public attention in Italy. See online: $<$ https://www.progettoinnocenti.it/new/nostri-casi/il-caso-gulotta-accolta-la-revisione-dellergastolo-dopo-22-annidi-carcere/>.

${ }^{45}$ Guglielmo Gulotta, Innocenza e Colpevolezza sul Banco degli Imputati (Milano: Giuffrè, 2018) [Gulotta] 212.

${ }^{46}$ Ferdinando Imposimato, L'errore giudiziario. Aspetti Giuridici e Casi Pratici. (Milano: Giuffrè, 2009) 179.

${ }^{47}$ Giulio Garofalo, "Da Lovanio ad Avetrana: "Appetito di Confessione" e Intolleranza alla Ritrattazione" [Garofalo] in Lupária \& Marafioti, supra note 42 at 115.

${ }^{48}$ Lupária 2. Some authors have noticed that such a distorted use of pre-trial detention still happens in judicial practice although the Italian Code of Criminal Procedure explicitly forbids to consider the suspect's refusal to render a statement as a ground to detain him.

${ }^{49}$ Garofalo, supra note 47 at 123.

${ }^{50}$ This is also due to the fact that the Code of Criminal Procedure does not require confessions to be 'corroborated' by other evidence in order to allow the judge to convict.

${ }^{51}$ Forensic science is the use of science to answer legal questions; the definition is provided by Garrett, supra note 10 at 85 .
} 
during the nineties. Forensic science itself, however, when it translates into forensic errors ${ }^{52}$ is also considered to be one of the most recurring causes for wrongful conviction. ${ }^{53}$

The expression 'forensic error' encompasses multiple instances of mistakes taking place at the various stages of collection, storage and analysis of evidence. First, physical evidence may be incorrectly handled during its collection and thus contaminated, ${ }^{54}$ with this error mainly happening at the beginning of the investigation. ${ }^{55}$ Second, even when evidence was correctly collected and stored, it may be analyzed using unreliable techniques. ${ }^{56}$ Thirdly, even when the methods used

${ }^{52}$ The issue of 'forensic error' is extensively addressed in specialized literature; George Castelle \& Elizabeth F Loftus "Misinformation and Wrongful Convictions" in Sandra D Westervelt \& John A Humphrey, eds, Wrongly Convicted, Perspectives On Failed Justice (New Brunswick: Rutgers University Press, 2001); Itiel E Dror, David Charlton \& Alisa A Péron, "Contextual Information Renders Experts Vulnerable to Making Erroneous Identifications" (2006) 156 Foren Sci Int'1 74; Mark Godsey "The Human Factor in Wrongful Conviction" [Godsey 3] in Luca Lupária, ed, Understanding Wrongful Conviction: The Protection Of The Innocent Across Europe And America (Milano: Wolters Kluwer, 2015) 18 [Lupária 1]; Mark Godsey \& Marie Alou, "She Blinded Me with Science: Wrongful Convictions and the 'Reverse CSI-Effect" (2011) 17:4 Tex Weleyan L Rev 481 [Godsey \& Alou]; David A Harris, Failed Evidence: Why Law Enforcement Resists Science (New York: New York University Press, 2012); Barry Scheck \& Peter Neufeld, "DNA and Innocence Scholarship" in Sandra D Westervelt \& John A Humphrey, eds, Wrongly Convicted, Perspectives On Failed Justice (New Brunswick: Rutgers University Press, 2001) [Westervelt \& Humphrey]; Beatrice Schiffer \& Christophe Champod, "Judicial Error and Forensic Science: Pondering the Contribution of DNA Evidence" Huff \& Killias, supra note 8 at 33; Juelle Vuille, Alex Biedermann \& Franco Taroni, "Accounting for the Potential of Error in the Evaluation of the Weight of Scientific Evidence" [Vuille, Biedermann \& Taroni] in Lupária 1, supra note 16 at 39.

${ }^{53}$ In the U.S., a fundamental turning point for the awareness of the problems linked to 'forensic errors' has been the publication in 2009 of a report by the prestigious National Academy of Science, Committee on Identifying the Needs of the Forensic Sciences Community, National Research Council, Strengthening Forensic Science in the United States: A Path Forward (Washington, DC, NRC, 2009). This publication, released on 18 February 2009 after three years of studies carried out by the Committee on Identifying the Needs of the Forensic Sciences Community and the Committee on Applied and Theoretical Statistics, has clearly underlined the necessity of a serious and critical reevaluation of the entire world of forensic science. For the literature's comments of the report, see D Michael Risinger, "Whose Fault?-Daubert, the NAS Report, and the Notion of Error in Forensic Science" (2010) 38 Fordham Urb LJ 519; D Michael Risinger, "The NAS/NRC Report on Forensic Science: A Path Forward Fraught with Pitfalls" (2010) Utah L Rev 225; Paul C Giannelli (2012) The 2009 NAS Forensic Science Report: A Literature Review, Faculty Publications, Paper no 99, online: 〈https://scholarlycommons.law.case.edu/faculty publications/99〉.

${ }^{54}$ M Finnebraaten, T Graner \& P Hoff-Olsen, "May A Speaking Individual Contaminate the Routine DNA Laboratory?" (2008) Forensic Sci Int'l 421; Nicholas J Port, Victoria L Bowyer, Eleanor A Graham, Madu Batuwangala \& Guy N Rutty, "How Long Does It Take A Static Speaking Individual to Contaminate the Immediate Environment?" (2006) 2:3 Forensic Sci Med \& Pathol 157; Adam L Poy \& Roland A H Van Oorschot, "Beware; Gloves And Equipment Used During The Examination Of Exhibits Are Potential Vectors For Transfer Of DNAContaining Material" (2006) 1288 Int'l Congress Series 556. When talking about DNA analysis, the authors highlight that other risks are the use of non-pertinent DNA samples and the neglect of other scientific and circumstantial evidence.

${ }^{55}$ Italian scholars have noted that urgent activities carried out by police officials at the preliminary stage of an investigation pose a high risk of evidence contamination, as there is no provision devoted to the specific techniques that ought to be used in order to preserve the evidence.

${ }^{56}$ A method is considered to be unreliable when - according to the scientific community - it does not provide consistent or accurate results; see Garrett, supra note 10 at 86. Instances of unreliable techniques are bite-mark or ear- 
were reliable, invalid conclusions may still be drawn from them, ${ }^{57}$ as might happen if available data are misinterpreted and/or the obtained results are presented at trial in a misleading way. ${ }^{58}$

All the above-mentioned mistakes and their impact on the outcome of the trial can be exacerbated by other contributing factors. Indeed, experts are often biased because they either work for the prosecution or have been provided with specific details of the case; which might mean that the conclusions they present are not fully impartial. ${ }^{59}$ In addition to this, legal practitioners both judges and lawyers - are lacking the scientific knowledge it would take to understand whether a forensic method is reliable and how valid the conclusions presented by the expert are.

The scope of this paper prevents us from offering a complete overview of the most common instances of forensic error; for this reason, in this part we will focus on a specific kind of forensic error that has received less attention compared to its 'brothers', albeit quite common: wiretapping error. ${ }^{60}$ Indeed, Italian prosecutors make wide use of interceptions, especially when they are investigating organized crime. ${ }^{61}$ Furthermore, when mafia-type associations or other serious crimes are involved, the grounds upon which interceptions can be obtained are extremely ample, thus making it possible for intercepted communications to be one of the first pieces of evidence collected by the prosecutor.

Although the issue of wiretapping errors has not been thoroughly analyzed by scholars, numerous cases of wrongful conviction based on mistaken interceptions have been reported by NGOs. ${ }^{62}$ Among the most recurring mistakes are wrong voice identifications, flawed transcriptions and poor comprehension of the content of the communication.

mark comparison. Another topic quite related to unreliable techniques is the one of unreliable scientific theories, like the SBS, Shaken Baby Syndrome; see Deborah Tuerkheimer, "The Next Innocent Project: Shaken Baby Syndrome and the Criminal Courts" (2009) 87 Wash U L Rev 1.

${ }^{57}$ Itiel E Dror, David Charlton \& Alisa A Péron, "Subjectivity and Bias in Forensic DNA Mixture Interpretation" (2011) 51:4 Sci \& Just 204; William C Thompson, "Painting the Target Around the Matching Profile: The Texas Sharpshooter Fallacy in Forensic DNA Interpretation" 8 Law Prob \& Risk 257.

${ }^{58}$ As an example, scholars and scientists have warned that it is invalid for the analyst to conclude that the DNA could only have come from the defendant; on the contrary, the analyst should only present the relevant statistics; in terms, Garrett, supra note 10 at 101. See also Godsey and Alou, supra note 52; Juelle Vuille, Luca Lupária \& Franco Taroni, "Scientific Evidence and the Right to a Fair Trial Under Article 6 ECHR" (2017) 16 Law Prob \& Risk 55.

${ }^{59}$ Itiel E Dror, David Charlton \& Alisa A Péron, "Contextual Information Renders Experts Vulnerable to Making Erroneous Identifications" (2006) 156 Foren Sci Int'1 75; Schiffer \& Champod in Huff \& Killias, supra note 8. As it has been noted, 'forensic analysts do not do their work blind'.

${ }^{60}$ Helen Fraser, "How Interpretation of Indistinct Covert Recordings Can Lead to Wrongful Conviction: A Case Study and Recommendations for Reform” in Ron Levy, Molly O’Brien, Simon Rice, Pauline Ridge \& Margaret Thornton, eds, New Directions for Law in Australia: Essays in Contemporary Law Reform (Canberra: ANU Press, 2017).

${ }^{61}$ Here, it suffices to notice that the prosecutor wishing to intercept a suspect needs to file a request to the preliminary investigation judge, who will rule upon the request and authorize the wiretapping to commence. See art $266 \mathrm{cpp}$.

${ }^{62}$ See online: <https://www.errorigiudiziari.com/?s=intercettazioni>; many of the cases that were reported, however, involved unjustified pre-trial detention rather than wrongful convictions. As we will see in this paragraph, such a phenomenon is in part to be attributed to the possibility of using 'summaries' of the intercepted communications in order to request pre-trial detention. 
Such recurring errors appear to be consistent with the 'wiretapping risks' observed by the few scholars that have addressed the issue; indeed, it has been noted that every phase of the interception process is prone to error. First, during the listening stage difficulties may be caused by background noises or by obsolete recording instruments; furthermore, those who speak may use different languages or dialects, talk extremely fast or try to mask their voice. Second, during the transcription stage operators may neglect to write down what they did not understand or fail to add details concerning intonation or pauses. Third, during the comprehension stage, difficulties may arise out of grammatically incorrect sentences or the use of dialects; moreover, the operator might fail to understand the intent of those who were speaking, the inferences they made during the conversation or the correct meaning of specific words.

Some possible causes underlying these mistakes might be better understood if one just pays attention to the wiretapping rules provided by the Italian Code of Criminal Procedure. During the investigating stage, after judicial authorization has been granted, the police is the one invested with the task of listening, recording and summarizing the content of the intercepted communications (summaries are called brogliacci). Both records and summaries are routinely sent to the public prosecutor, who can use them to request pre-trial detention and afterwards to request the case be brought to trial. ${ }^{63}$

The fact that the police are the ones summarizing the content of the intercepted communication poses itself a huge risk: police officials, indeed, suffer from an almost universally recognized confirmation bias $;{ }^{64}$ they know the facts of the case, are aware of who the suspects are and of the evidence already collected against them. They may therefore be far from impartial when de-coding the content of a conversation in which the suspect is involved.

For the intercepted communications to be used as evidence at trial, however, both the prosecutor or the defendant have to ask the judge to appoint an impartial expert that will listen to the records and transcript them ex novo. ${ }^{65}$ The expert, however, is routinely authorized to use the summaries that were formed by police officials. The main concerns that arise out of this mechanism are two: first, if the expert resorts to the summaries formed by the police, she might concur in the same mistakes committed by police officials (if any, of course). Second, there is no provision obliging the judge to appoint as expert someone who has studied psycholinguistics. Finally, although scholars have warned against the use of voice comparison techniques sometimes described as a 'totally distorted forensic discipline" ${ }^{66}$ - such methods are still used in court.

\footnotetext{
${ }^{63}$ See art $268 \mathrm{cpp}$.

${ }^{64}$ Confirmation bias is defined as "The seeking or interpreting of evidence in ways that are partial to existing beliefs, expectations or a hypothesis in hand" - Raymond S Nickerson, "Confirmation Bias: A Ubiquitous Phenomenon In Many Guises, (1988) 2 Rev Gen Psychol 175. See also Godsey 3, supra note 52 at 18; Godsey 1, supra note 36 at 90.

${ }^{65}$ See art 268 (7) and 493-bis cpp; the jurisprudence of the Italian Supreme Court, however, has clarified that failing to transcribe the intercepted communications does not - per se - render them inadmissible at trial.

${ }^{66}$ Garrett, supra note 10 at 106.
} 


\section{c. Misidentification}

False eyewitness identification of the accused is considered to be the foremost cause of wrongful conviction worldwide ${ }^{67}$ Even though scholars agree about the high unreliability of identification procedures, the statement of a witness, or worse, the victim recognizing the suspect is still an extremely powerful piece of evidence. Eyewitness identification, alone, may suffice to convict an individual.

Two issues have been identified as the main problematic aspects of identification procedures; first, human memory is extremely fragile and malleable, in spite of how certain the witness claims to be. Furthermore, repetitive identification procedures - quite common in judicial practice - can cement false memories by making a wrong person look more familiar. ${ }^{68}$ Second, law enforcement procedures have a huge impact on the outcome of an identification and, when flawed, definitively crash its genuineness. ${ }^{69}$

Among the most recurring factors that impinge upon the outcome of identification are remarks or suggestions made by police officials, both before and after the witness has answered; the construction of a line-up in a way that one single individual blatantly stands out among the others; worse than all, show-up identifications in which the witness is presented with only one individual and asked if she recognizes him. ${ }^{70}$ As an aggravating circumstance, it is extremely difficult to understand how properly the identification was conducted, as such procedures are rarely documented; even when there is a report, it simply states the outcome of the procedure, without mentioning the way in which it took place.

Eyewitness identification has long been at the center of academic debate among Italian scholars, due to elusive prosecutorial and judicial practices. Indeed, the Italian Code of Criminal Procedure (art. 213-214) contains a very detailed discipline of judge-conducted eyewitness identification (ricognizione), thus proving the distrust that the legislator had towards this specific mechanism and underlining the necessity to ensure its reliability.

First, the judge needs to ask the witness to describe the suspect, to recall whether she was called for previous identifications or if she has otherwise seen the person and to explain if there are any other circumstances that may have an impact upon the identification's reliability. Then, after the witness is temporarily removed from the setting, the judge has to make sure that at least two other individuals are presented to her - together with the suspect - and that those individuals

\footnotetext{
${ }^{67}$ Brian L Cutler \& Steven D Penrod, Mistaken Identification: The Eyewitness, Psychology And The Law (New York: Cambridge University Press, 1995); Elizabeth Loftus, Eyewitness Testimony (Cambridge: Harvard University Press, 1979); Gary Wells \& Elizabeth Olson, "Eyewitness Testimony” (2003) 54 Ann Rev Psychol 277: Gary L Wells, Mark A Small, Steven D Penrod, Roy S Malpass, Solomon M Fulero, C Elizabeth Brimacombe, "Eyewitness Identification Procedures: Recommendations for Lineups and Photo Spreads" (1998) 22 Law \& Human Behav 603.

${ }^{68}$ Scholars speak of a 'following visualization effect' - effetto della visualizzazione successiva; see Gulotta, supra note 45 at 289.

${ }^{69}$ Some authors have noted that in $78 \%$ of flawed identification cases there was evidence that police had contaminated the procedure. See Garrett, supra note 10 at 49.

${ }^{70}$ Garrett, ibid at 45 .
} 
are as similar as possible to the suspect. After the witness returns, the judge asks if she recognizes anyone and, if positive, whether she is certain.

All those guarantees and procedural steps, however, almost disappear in the everyday judicial practice. First, judges do admit as evidence in court the minutes of previous identifications conducted by the police or the prosecutor during the investigative phase - albeit those subjects are not bound to respect the same procedural steps that we have described above. Moreover, during the investigation, identifications are frequently conducted using photographs and not live line-ups, although this technique is far less reliable. ${ }^{71}$

Secondly, Italian jurisprudence has for a long time allowed identifications to take place in Court, during the hearing, with the prosecutor asking the witness if she recognizes the culprit in the courtroom. However, in the courtroom the suspect is standing alone, next to her lawyer, in the defendant's bench, or worse, in a cage.

The hiatus that exists between the law on the books and judicial practice has been vigorously stigmatized by scholars, as it blatantly overlooks all the guarantees and procedural steps that should be respected in order to ensure identifications' reliability.

\section{d. Pentiti: The Italian Counterpart of U.S. Jailhouse Informants?}

Another cause for wrongful convictions upon which there is ample consensus among scholars concerns a specific kind of testimony, the one provided by 'incentivized witnesses' (i.e., the so-called jailhouse informants or snitches). ${ }^{72}$ The adjective 'incentivized' underlines that these witnesses are strongly motivated by the institutional rewards awaiting them if they (even falsely) testify in support of the prosecutor's theory. ${ }^{73}$ Because of that, they are frequently willing "to shape their stories to fit whatever is needed". ${ }^{4}$

As it has been noted, the American criminal system makes wide use of this kind of testimony ${ }^{75}$ although it has long been proved incredibly unreliable. Whether the informant is specifically placed in the same cell as the suspect, or she 'spontaneously' approaches the prosecutor to provide information, the pattern is quite recurring. The informant is usually someone

\footnotetext{
${ }^{71}$ Indeed, scholars have highlighted that photographs shown during an identification are often low-resolution ones, and that while posing individuals tend to assume unnatural facial expressions.

${ }^{72}$ With this respect see Robert M Bloom, "Jailhouse informants" (2003) 18:1 Crim Just 20; Brandon L Garrett, "Trial and Error" in Huff and Killias, supra note 8; Alexandra Natapoff, "Beyond Unreliable: How Snitches Contribute to Wrongful Convictions" (2006) 37 Golden Gate U Law Rev 107; Jeffrey S Neuschatz, "The Effects of Accomplice Witnesses and Jailhouse Informants on Jury Decision Making" (2008) 32 Law \& Human Behav 137; Kent Roach, "Unreliable Evidence and Wrongful Convictions: The Case for Excluding Tainted Identification Evidence and Jailhouse and Coerced Confessions" (2007) 52 Crim LQ 210; Robert W Stewart, "Jailhouse Snitches: Trading Lies for Freedom" Los Angeles Times (16 April 1989); Clifford Zimmerman, "From The Jailhouse To The Courthouse: The Role Of Informants In Wrongful Convictions" in Westervelt \& Humphrey, supra note 52.

${ }^{73}$ Richard A Leo, "Rethinking the Study of Miscarriages of Justice: Developing a Criminology of Wrongful Conviction" (2005) 21:3 J Contemp Crim J 201 at 207.

${ }^{74}$ C Ronald Huff, "Wrongful Convictions in the United States" in Huff and Killias, supra note 8 at 63.

${ }^{75}$ Godsey 1, supra note 36 at 205.
} 
with previous convictions or currently facing charges; she strongly denies having ever met the defendant before ${ }^{76}$ she claims to have directly or indirectly heard the defendant confess to the crime for which he is standing trial; she is able to provide specific details of the crime that only the culprit might have known. ${ }^{77}$ Frequently, her statement perfectly fits the prosecution's case. She usually denies having made any sort of a deal with the prosecution (with this being corroborated by the prosecutor's own denial), yet the charges against her are subsequently dropped or she receives a more lenient sentence ${ }^{78}$ Even though all the previous observations should cast serious doubts about the reliability of such witnesses, juries do credit their statements, either because of their accuracy or because the prosecutor firmly denies having promised any reward.

The issue of jailhouse informants has not gotten much attention in the Italian literature; this is probably due to the fact that Italian prosecutors are bound by the compulsory prosecution principle, enshrined in art. 112 of the Constitution. As such, they simply cannot drop charges or adhere to less serious charges in exchange for cooperation - and therefore have little to offer to potential informants. Theoretically (and if they are the ones in charge of the case) prosecutors might ask for a lighter sentence if the informant or the co-defendant has cooperated, but since the issue has not been analyzed we have no proof that this happens in practice and, if it does, how often.

However, the Italian legislation specifically addresses a peculiar kind of incentivized witness, the so-called 'collaboratore di giustizia' (more commonly, pentito). ${ }^{79}$ Such a figure appeared during the political terrorism emergency of the past century, and during the last decades the legislator has extended its use to other instances of serious crimes: most notably, mafia-type organizations ${ }^{80}$ and - within the last year - political corruption. Pentiti have been extremely useful in the past, as they usually provide 'inside' information about criminal enterprises that would have otherwise remained secret. Because of how useful that information is to the fight against organized crime, and to 'balance' the dangers that pentiti undergo when they decide to cooperate with the State, they are 'awarded' with consistent sentence reduction and the possibility of accessing 'alternative measures' other than detention. ${ }^{81}$ On the other hand, individuals that are convicted for the same serious crimes for which cooperation is possible, and who refuse to cooperate, face the

\footnotetext{
${ }^{76}$ Garrett, supra note 10 at 132.

${ }^{77}$ Garrett, ibid at 124.

${ }^{78}$ Garrett, ibid. At p.129 the author notes that prosecutor, at their discretion and albeit having been vague with the informant about the possible benefits, may drop charges, pursue more lenient charges or a shorter sentence.

${ }^{79}$ See for some examples, art 289-bis, 323-ter cpp; DL 625/1979; L 304/1982; L 34/1987; DPR 309/1990.

${ }^{80}$ Sebastiano Ardita, "La Nuova Legge sui Collaboratori e sui Testimoni di Giustizia" (2001) 5 Cass. Pen 1698; Alessandra Dino, ed, Pentiti. I Collaboratori di Giustizia, Le Istituzioni, L'opinione Pubblica (Roma: Donzelli, 2006); Paolo Giordano, "Profili Premiali Della Risposta Punitiva Dello Stato" (1997) 3 Cass. Pen 916; Domenico Pulitanò, "Tecniche Premiali Fra Diritto e Processo Penale" 4 (1986) Riv I. Dir Proc Pen 1005; Carlo Ruga Riva, Il Premio per la Collaborazione Processuale (Milano: Giuffrè, 2002).

${ }^{81}$ The recently introduced art 323-ter of the Italian Criminal Code, concerning political corruption, goes as far as to award co-defendants that cooperate with impunity.
} 
quasi-impossibility of accessing the same alternative measures. ${ }^{82}$ It is thus fair to say that the Italian State does, in fact, push some defendants to cooperate with the prosecutor.

Our intention is nowhere near to that of underestimating the importance that pentiti's declarations have had in the past; without them, most of what we currently know about mafia-type organizations' structure would have been almost impossible to discover. However, there seems to be quite enough consensus among scholars that, in order to obtain a lighter sentence or for reasons of personal vengeance, it has in fact happened that pentiti have provided false statements leading to the conviction of innocent people. ${ }^{83}$ The most famous case is probably that of late Enzo Tortora ${ }^{84}$ at the time being one of the most prominent Italian journalists, arrested and tried on drug charges because of what turned out to be entirely made up statements coming from multiple pentiti.

As observed by NGOs, the Tortora case is not isolated, and the list of individuals falsely implicated in the commission of a crime by pentiti's declarations is continuing to grow. ${ }^{85}$ This might be due to the fact that Italian jurisprudence currently allows convictions to be founded upon multiple pentiti's statements, as long as they corroborate each other. ${ }^{86}$ This 'riscontri incrociati' argument, however, makes it possible for pentiti to agree on a specific version of the events, in order for their declarations to be considered reliable and usable in Court (and for them to obtain benefits or vengeance). ${ }^{87}$

\section{B. Learning from the Americans: The Need for a National Registry of Exonerations and Conviction Integrity Units}

The brief summary of probable causes for wrongful convictions we have provided might lead the reader to believe that, as it has been done in the U.S., Italian scholars have had the opportunity of accessing case files and analyzing previous cases of wrongful convictions, in order to gain a precise knowledge of past mistakes, the trial stage in which they occurred and their frequency. Once again, reality is quite different from imagination.

As it has already been noted, the Italian system does not provide accurate statistics or research concerning wrongful convictions, despite having had to face many 'infamous' instances of such a phenomenon in the past. ${ }^{88}$ The Ministry of Justice is not bound nor is spontaneously required to publish any official data concerning wrongful conviction cases, let alone disclose the original case materials in order for scholars to study them in the context of a case-by-case analysis.

\footnotetext{
${ }^{82}$ See art 4-bis of the law on the penitentiary system, L 354/1975. These kind of limitations, however, are starting to be dismantled by the Italian Constitutional Court, see judgment n 253/2019; see also ECtHR, app n 77633/16, Viola $\checkmark$ Italy.

${ }^{83}$ See online: $<$ https://www.errorigiudiziari.com/OLD/tag/false-dichiarazioni-pentiti/>.

${ }^{84}$ English speaking readers may find a summary of the Tortora case here: online:

$<$ https://en.wikipedia.org/wiki/Enzo_Tortora>.

${ }^{85}$ See online: 〈https://www.errorigiudiziari.com/OLD/tag/false-dichiarazioni-pentiti/〉.

${ }^{86}$ See Italian Court of Cassation, sec VI, 14/06/2018, sentence n 40899.

${ }^{87}$ Gulotta, supra note 45 at 223.

${ }^{88}$ Lupária 1, supra note 16 at 5.
} 
This means that besides cases in which lawyers (or exonerees) themselves have shared the facts and files of 'their' wrongful conviction, Italian scholars have few possibilities of identifying with sufficient certainty both the legal and the root causes of the 'Italian miscarriage of justice'. We don't know the percentage of cases in which identification procedures were conducted in an informal way; we don't know how often police officials and forensic experts contaminate evidence; we don't know in how many cases the official transcribing of interceptions had no expertise in psycholinguistics; we don't know in how many cases the defendant was subject to undue pressure while questioned; we have no clue of the number of cases in which pentiti's declarations were not corroborated by other evidence. Worse of all, we don't know if there are other causes specific to the Italian system, absent in other countries, that might explain our escalating figures of wrongful convictions.

All we know is that scholars have long been warning that there is often a huge hiatus between the guarantees and procedural safeguards provided by law and every-day judicial practice; yet the same scholars are not able to assess what qualitative and quantitative impact this hiatus is currently producing on trial outcomes. Simply stated, we know that the law is not always strictly followed by police officials, prosecutors and judges, yet we cannot provide certain data about the influence that these kinds of malpractices have on wrongful convictions (albeit knowing that wrongful convictions are in fact occurring).

The negative impact of this lack of knowledge cannot be underestimated; to decrease the number of wrongful convictions, systemic and judicial culture changes are needed. Yet, if there is no reliable data on what the real, Italian, causes of wrongful convictions are, it is hard to figure in which direction to change. What we need to understand, therefore, is what are the most common errors, at what stage of the proceeding they occur and what are the roots causes behind them (e.g., chance, human fallibility, institutional deficiencies). ${ }^{89}$ In this respect, Italy has much to learn from the U.S. experience. ${ }^{90}$

Needless to say, American scholars have conducted in depth, case by case analysis of wrongful convictions. ${ }^{91}$ Accurately studying case files made it possible for them to precisely identify what mistakes were occurring, at what stage of the proceeding, with what frequency and who was responsible. Such precise knowledge has led to well-founded reform proposals, often implemented both through legislation or guidelines. ${ }^{92}$ Most importantly, American scholars have at their disposal an extremely powerful tool: the well re-known National Registry of

\footnotetext{
${ }^{89}$ Eric Colvin, "Convicting the Innocent: A Critique of Theories of Wrongful Convictions" 20 Crim LF 173. Italy is not the only country in which there has been no extensive case-by-case study; see also David T Johnson, "Wrongful Convictions and the Culture of Denial in The Culture of Capital Punishment in Japan" in Palgrave Advances in Criminology and Criminal Justice in Asia Book Series (Palgrave: Pivot Cham, 2020).

${ }^{90} \mathrm{We}$ must however note that, to our knowledge, the absence of an official database is common to each and every European Country; the American National Registry of Exonerations itself is provided by the University of California, the Irvine Newkirk Centre For Science \& Society, the University Of Michigan Law School \& Michigan State University College of Law, and not by the U.S. Government.

${ }^{91}$ Russell Covey, "Police Misconduct as a Cause of Wrongful Convictions" (2013) 90 Wash U L Rev 1133; Scheck, Neufeld \& Dwyer, supra note 7.

${ }^{92}$ Mark Godsey, "False Justice and the 'True' Prosecutor: A Memoir, Tribute, and Commentary" (2012) 9 Ohio St J Crim L 789 [Godsey 4].
} 
Exonerations. ${ }^{93}$ Currently counting 2,555 exonerations since 1989, the Registry provides (to everyone and for free) accurate information on each and every exoneree's case, with the additional possibility for practitioners to request case files. Such an enormous database enables scholars to easily obtain the information and data they need to build their own theory on the causes of wrongful convictions, to advance reform proposals and to share awareness. As a leading scholar has noted, "The National Registry may be the wave of the future for the next generation of American wrongful conviction studies". 94

The American experience, in this respect, must serve as an example for every European judicial system. The Italian Innocence Project is currently working to have an equivalent of the National Registry of Exonerations established in Italy, providing detailed information on all the cases where final convictions were reversed in a revision trial. ${ }^{95}$ Needless to say, the cooperation of national institutions is of paramount importance: not only it would render the collection and storage of data an easier task, but it would also help national institutions to become more aware of the issue of wrongful conviction.

This observation leads us to the second aspect of the U.S. experience that should serve as an example for Italy: the judiciary needs to be involved in the process of preventing and reversing wrongful convictions. In Italy, the Prosecutor is allowed to ask for a revision process, yet this rarely occurs sua sponte. As the decrease in the number of wrongful convictions serves the purpose of justice, and not merely that of the defendant, judges and prosecutors should not consider the work of Innocence Projects as 'disturbing' the normal course of justice, but rather as a precious instrument to decrease the risk of judicial errors being made.

In the U.S. (albeit not always) there have been virtuous examples of prosecutors and district attorneys cooperating with Innocent Projects and lawyers to shed light on previous 'dubious' convictions. $^{96}$ More importantly, the rise of Innocence Projects has brought many U.S. Prosecutor's Offices to establish "Conviction Integrity Units" (C.I.U.); they are divisions of prosecutorial offices that work to prevent, identify, and remedy false convictions. ${ }^{97}$ In less than 20 years (the first unit was established in 2002), CIUs have secured 390 exonerations, thus proving the astonishing results that serious cooperation between the prosecutor and the defense can produce. ${ }^{98}$ As Italian prosecutors already have the power to ask for a revision process, it is not

\footnotetext{
${ }^{93}$ Online: 〈https://www.law.umich.edu/special/exoneration/Pages/about.aspx $>$.

${ }^{94}$ Richard A Leo, "The Criminology of Wrongful Conviction: A Decade Later" (2017) 33 J Contemp Crim J 82.

${ }^{95}$ The importance of comprehensive databases in wrongful conviction literature's methodology is stressed by Richard A Leo, "Rethinking the Study of Miscarriages of Justice: Developing a Criminology of Wrongful Conviction" (2005) 21:3 J Contemp Crim J 201 at 216.

${ }^{96}$ Godsey 4, supra note 92; Lupária 1, supra note 16 at 5; Jim Petro \& Nancy Petro, False Justice: Eight Myths That Convict the Innocent (New York: Kaplan Publishing, 2010).

${ }^{97}$ For a list of the existing CIUs see online: <https://www.law.umich.edu/special/exoneration/Pages/ConvictionIntegrity-Units.aspx>.

${ }^{98}$ Kay L Levine \& Ronald F Wright, "Prosecutor Risk, Maturation, and Wrongful Conviction Practice" (2017) 42:3 Law \& Soc Inq 648; Barry Scheck, "Professional and Conviction Integrity Programs: Why We Need Them, Why They Will Work, and Models for Creating Them" (2010) 31 Cardozo L Rev 2215; Mike Ware, "Dallas County Conviction Integrity Unit and the Importance of Getting It Right the First Time" (2010) 56 NY Law Sch Rev 1033.
} 
difficult to imagine the benefits that the establishment of similar units might have within the Italian criminal system.

\section{Conclusions. Learning from the Italians: Plea Bargaining Limitations}

Even if the Italian path towards a decrease in wrongful convictions still looks quite long, we do believe that our criminal justice system is equipped with some mechanisms that do serve this purpose. Thus, while we might still need to learn from other countries' experiences to improve our approach to the issue of wrongful convictions, in this last part we would like to highlight one aspect of our system that we believe could be of inspiration: Italy's version of plea bargaining. ${ }^{99}$

Many scholars share the opinion that plea bargaining carries with it a significant risk of wrongful conviction; ${ }^{100}$ it has indeed been demonstrated that innocent defendants might well accept to plead guilty despite being deeply convinced of their innocence. ${ }^{101}$ This counter-intuitive choice happens for a variety of reasons: the defendant might be 'confused' with respect to the charges brought against her, she may be pressured by her lawyer ${ }^{102}$ or she might have the feeling that the evidence of her guilty is seemingly overwhelming. More than that, however, she simply

\footnotetext{
${ }^{99}$ Obviously, we do not believe that plea bargaining limitations are the only positive aspect of the Italian criminal system; many other national mechanisms, indeed, are (also) designed in order to avoid 'unsafe convictions': examples might be drawn from the Court's power to order additional evidence to be produced or from the possibility of Court appointed experts to analyze evidence and testify. Such mechanisms, however, are deeply rooted in the inquisitorial tradition, and it would be extremely difficult to transplant them into traditionally adversarial systems. Plea bargaining, on the contrary, is a typical 'common law mechanism', that the Italian system has 'borrowed' from its oversea counterpart, albeit deeply modifying it. As such, it might be less traumatic for adversarial-accustomed scholars and practitioners to look at the Italian version of plea bargaining as a source for inspiration. Indeed, some authors in the U.S. have already advanced the proposal to adopt the 'European Plea-Bargaining solution', see Killias \& Huff "Wrongful Convictions and Miscarriages of Justice - What Did We Learn? in Killias \& Huff, supra note 20 at 389. ${ }^{100}$ John J Baldwin \& Michael McConville, Negotiated Justice: Pressures to Plead Guilty (London: Martin Robertson, 1977); Josh Bowers, "Punishing the Innocent" (2008) 156:5 U Penn L Rev 1117; Lucian E Dervan, "Bargained Justice: Plea-Bargaining's Innocence Problem and the Brady Safety-Valve" (2012) 51 Utah L Rev 61; Oren Gazal-Ayal, "Partial Ban on Plea Bargains" (2005) 27 Cardozo L Rev 2295; F Andrew Hessick \& Reshma M Saujani, "Plea Bargaining and Convicting the Innocent: The Role of the Prosecutor, the Defense Counsel, and The Judge" (2002) 16 BYU J Pub L 189; Wes R Porter, "Threaten Sentencing Enhancement, Coerce Plea, (Wash, Rinse,) Repeat: A Cause of Wrongful Conviction by Guilty Plea" (2015) 3 Tex A\&M L Rev 26; Douglas A Smith, "Plea Bargaining Controversy" (1986) 77 J Crim L Criminol 949; AN Stern, "Plea Bargaining, Innocence, and the Prosecutor's Duty to "Do Justice" (2012) 25 Geo J Legal Ethics 1027.

101 The most recent data provided by the National Registry of Exoneration prove that $15 \%$ of those exonerees pleaded guilty; this number might seem non-significant, if one considers that $95 \%$ of U.S. trials end up in plea agreements, see online: 〈https://www.law.umich.edu/special/exoneration/Pages/Guilty-Pleas.aspx >. However, it has been noted that the legal and practical barriers to obtain an exoneration if one has pleaded guilty are extremely high, when compared to those that decided to face trial. See Albert Alschuler, "A Nearly Perfect System for Convicting the Innocent" (2017) 612 U Chicago Pub L \& Legal Theory Paper Series 931.

${ }^{102}$ See the 'meet'em and plead'em defense lawyers' in Garrett, supra note 10 at 151.
} 
might accept the plea deal the prosecutor is offering is so convenient that it clearly overbalances the chance of acquittal she feels might occur if she goes to trial. ${ }^{103}$

Indeed, some authors have argued that in the American system "The prosecutor can reduce the offered punishment to the point that it will become advantageous for the defendant to plead guilty whether he is guilty or innocent". ${ }^{104}$ In this respect, the limitations that the majority of European systems ${ }^{105}$ and, more specifically, Italian law, impose when it comes to plea bargaining (the so called patteggiamento, art. 444 c.p.p.) ${ }^{106}$ might decrease such a risk. In fact, plea bargaining is only available when the charges might lead to a sentence not longer than five years of imprisonment; ${ }^{107}$ moreover, the deal offered by the prosecutor can neither involve a discretionary modification of the charges nor decrease the sentence of more than one third of the minimum penalty provided by law. Once there is agreement between the prosecutor and the defendant, it will then be up to the judge to verify whether the legal qualification of the facts is correct and the proposed sentence appropriate. As such, prosecutors, in principle, could not advance such appealing proposals so as to convince an innocent defendant to accept the deal. ${ }^{108}$

These last remarks allow us to conclude that thirty years ago, the continental and the American legal systems could not be any more different and the issue of wrongful convictions was rarely to be found in the public and academic debate. Within the span of just three decades, both conclusions stated came to be false. On the one hand, European criminal systems slowly

\footnotetext{
${ }^{103}$ See among others, Victoria Colvin, "Plea Bargaining and Miscarriage of Justice: A Case Study of the Prosecution of Gabe Watson, the So-Called Honeymoon Killer" (2015) 34 UQLJ 71; Murat C Mungan \& Jonathan Klick, "Reducing False Guilty Pleas and Wrongful Convictions through Exoneree Compensation" (2016) 59 JL \& Econ 173.

${ }^{104}$ Albert Alschuler, "A Nearly Perfect System for Convicting the Innocent” (2017) 612 U Chicago Pub L \& Legal Theory Paper Series 920.

${ }^{105}$ Indeed, it has been observed that almost every continental system nowadays, provides with some sort of plea bargaining or a functional equivalent - Jackson, Langer \& Tillers, supra note 21 at 8; yet, within the Continent plea bargaining is only allowed in very limited circumstances and for minor offenses. See Killias \& Huff "Wrongful Convictions and Miscarriages of Justice - What Did We Learn?" in Killias \& Huff, supra note 20 at 381.

${ }^{106}$ Maximo Langer, "From Legal Transplants to Legal Translations: The Globalization of Plea Bargaining and the Americanization Thesis in Criminal Procedure" (2004) 45 Harvard Int'l LJ 1; JJ Miller, "Plea Bargaining and Its Analogues under the New Italian Criminal Procedure Code and in the United States: Towards a New Understanding of Comparative Criminal Procedure" (1989) 22 NYU J Int'l L \& Pol 215; RA Van Cleave, “An Offer You Can't Refuse? Punishment Without Trial in Italy and the United States: The Search for Truth and an Efficient Criminal Justice System" (1997) 11 Emory Int'l L Rev 419.

${ }^{107}$ However, the Italian Government has recently approved a proposal (disegno di legge) whose goal is to allow patteggiamento to take place when the charges might lead to a sentence not longer than eight years of imprisonment, thus increasing the maximum penalty for which it is possible to plead guilty. This proposed amendment should, in principle, contribute to a decrease in the duration of criminal proceedings; yet, it might have a negative impact on the numbers of wrongful convictions, as it allows those who have been accused of (also) serious crimes to waive their right to trial in exchange for more lenient sentences. For a summary of all the amendments that the abovementioned proposal contains, see online: <http://www.quotidianogiuridico.it/documents/2020/02/19/riforma-del-processopenale-e-prescrizione-il-testo-del-disegno-di-legge>.

${ }^{108}$ Once again, unfortunately, the lack of data concerning Italian wrongful convictions prevents us from knowing how many, if any, of the approximately 153 cases that have been reported since 1991 involved a patteggiamento. For some critical remarks on the Italian patteggiamento see Lupária \& Gialuz, supra note 21.
} 
incorporated adversarial elements in their procedure, in order to establish equality of arms between the prosecution and the defendant and to strengthen the latter's guarantees. On the other hand, the adversarial system by definition, the U.S. one, had to face the harsh reality of wrongful convictions, a reality which in turn came to be acknowledged also across Europe. The rise of the innocence movement and the many legislative and procedural amendments that such an acknowledgement has brought represent milestones paving the long way to safer, more precise criminal justice systems. While not disregarding all the results that we have accomplished so far, we must acknowledge that our systems are yet full of flaws and that many individuals are still behind bars for crimes they did not commit. Learning from each other's mistakes and solutions seems to be the only way to grant these individuals the justice they, and we, all deserve. 